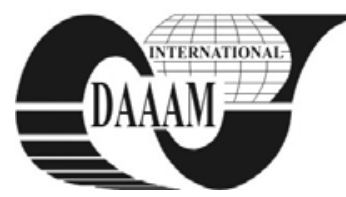

\title{
FORMALIZATION OF A METHODOLOGY FOR MEASURING OF THE NOISE FROM SMALL SPORTS AIRPORTS
}

\author{
BADIDA, M[iroslav]; HERCZNER, P[eter]; KONKOLY, J[ozef] \& LUMNITZER, E[rvin]
}

\begin{abstract}
The phenomenon of aircraft noise is not only cover of a major international airport, where is the traffic dense and intense as the transport of cargo and passenger aircraft, but also a problem of small sport airports that have less traffic overall. The proposed methodology has been developed for small sport airport and has been successfully tested on a small airport on sports aeroclub airport Kamenica nad Cirochou. Key words: environment, noise, small sport airports, air traffic
\end{abstract}

\section{INTRODUCTION}

This methodology will try to work comprehensively mapping all the essential elements that affect the calculation of the level of aircraft noise contours and noising from air traffic. Requirements for the calculation of aircraft noise can vary greatly depending on the nature of the airport, weather conditions, airport-type and other factors. Three separate parts of assessing aircraft noise process are shown in Fig. 1.

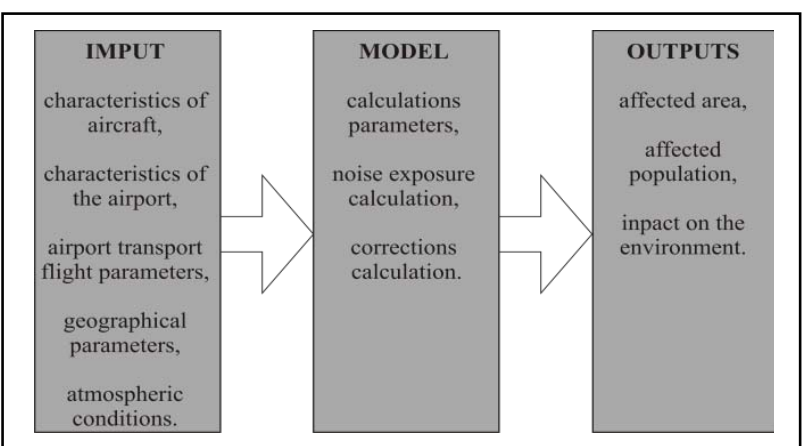

Fig. 1. Three parts of the assessment of aircraft noise

The proposed methodology implements all the necessary tools to calculate the noise level, which is emitted into the environment in the vicinity of airports.

\section{DESCRIPTION OF AIR TRACK}

Location of aircraft around an airport is defined fixed network coordination system. $\mathrm{X}$ and $\mathrm{Y}$ coordinates are designated as ground coordination system of coordinates and altitude as coordinate the opening climb of the aircraft, after reaching the point of $\mathrm{M}_{\mathrm{c}}$, as shown in Fig. 2.

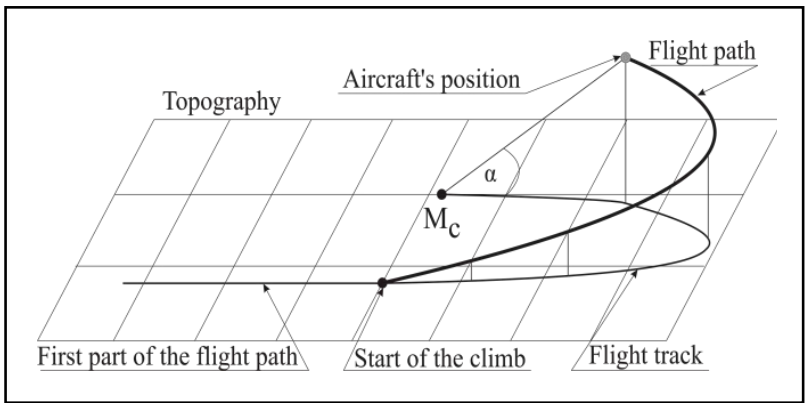

Fig. 2. Shooting aircraft flight path

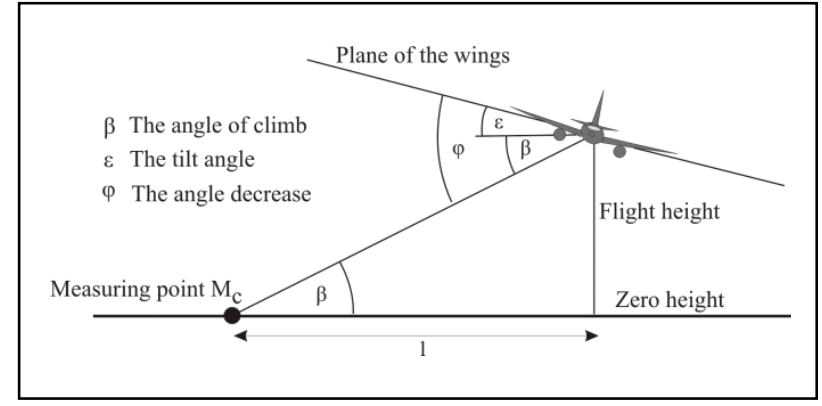

Fig. 3. Generalized location of measuring point

Coordinate system starting position is always at the measurement point Mc. The measurement point is shown in Fig. 3. N-distance of the aircraft's position will vary depending on the speed of the aircraft. The size of the grid and the network itself is determined individually, always in direct contact with the aircraft type, aircraft speed and the individual needs of the observer. According to the results obtained, which are measured from the observation point is calculated in the simulation time during the stress level while passing aircraft.

\section{CALCULATION OF AIRCRAFT NOISE}

\subsection{Basic calculation}

When measurements are generally used for spectral filter A weighting filter, which is close to approaching the sensitivity of the human ear and the time constant introduced "SLOW" air noise. Sound pressure is time-variable function that creates the output variable for the time value of the load. The resulting calculation of sound pressure level as a time variable function is then defined as:

$$
L_{A}(t)=10 \cdot \log \frac{p(t)^{2}}{p_{0}^{2}}
$$

Total measurement is always dependent on many factors. These factors alone have an impact on the measured values at the measurement point and then to calculate the actual noise and its impact on the environment. One factor which is introduced is the mean noise or equivalent noise level $\mathrm{L}_{\mathrm{eq}}$. Equivalent noise level is the energy average sound level spriemernenej during the measurement interval. It is defined as sound pressure level of continuous steady sound that within a time interval measurement $t=t_{2}-t_{1}$, has the same mean square sound pressure as a reference sound, which varies over time. The basis for the determination of measurement interval or the reference time and land - the sound pressures $L_{A(t)}$. The actual calculation of equivalent sound level $\mathrm{L}_{\mathrm{eq}(\mathrm{t})}$ is then defined as:

$$
L_{e q}(t)=10 \cdot \log \left[\frac{1}{t} \int_{t_{1}}^{t_{2}} 10^{\frac{L_{A}(t)}{10}} d t\right]
$$

\subsection{Speed correction}

Correction speed adjusts the speed of the aircraft itself. It is used when the speed of a certain segment of take-off runway is 
significantly different than the other segments, and thus significantly changed the reference speed Vref, which are contained in the database NPD. Around the track section is hereby set performance engine, so engine power and speed of the aircraft.

$$
\Delta V=10 \cdot \log \left(V_{\text {ref }} / V_{\text {seg }}\left(\text { resp. } V_{\text {seg, }, k o l}\right)\right)
$$

\subsection{Correction of the tilt plane}

Noise from air traffic is not only of themselves but the overall engine noise from the flight itself. Very significant impact on the noise of the airplane has a location, design and installation of engines on the aircraft. The increase in noise occurs when the aircraft itself is tilted and is significantly affected by the conduct of the process of reflection, refraction and scattering effects of noise on hard surfaces of take-off runway. The actual impact is then the uneven dispersion of the sound environment around the airport. It is then necessary to correct the slope of the aircraft itself. The actual calculation of the correction will be performed by the calculation formula, which contains the basic angles of inclination and length distance placing the engine on the wing.

$$
\left.\Delta I(\varepsilon)=10 \cdot \log \mid\left(a \cdot \cos ^{2} \varepsilon+\sin ^{2} \varepsilon\right)^{b} /\left(c \cdot \sin ^{2} 2 \varepsilon+\cos ^{2} 2 \varepsilon\right)\right]
$$

\subsection{Total correction}

Sedation after the summation of all of the corrections is then calculated as the sum of all of the corrections in chapters 3.2 to 3.3. $\mathrm{L}_{\mathrm{korr}}$ is then calculated according to:

$$
L_{\text {korr }}=\Delta V+\Delta I(\varepsilon)
$$

\subsection{The value of the load after correction $L_{\max }$}

Load value is always evaluated after accounting adjustments. For the actual calculation is used the equivalent sound level $\mathrm{L}_{\mathrm{eq}}$ if it is then added the necessary corrections. The actual calculation will be performed using the equation:

$$
L_{\max }=L_{e q}(t)+\sum_{i} L_{k o r r}
$$

The total amount $\mathrm{L}_{\text {korr }}$ examines all the disruptive effects of different types of noise in the same buffer $\mathrm{L}_{\mathrm{eq}}$. This variaty is introduced only for certain types of airports, always depending on the type of airports, especially in civil and military and the nature of the take-off runway and its individual segments.

\section{PRACTICAL APPLICATION}

The airport, where the measurements were carried out, is located east of the city Humenné. It is a civilian sport airport, which is incorporated into the network Aeroclub Slovakia. The airport is located in greenfield areas north of the village of Kamenica nad Cirochou.

The airport has two runways no. 07 take-off. and no. 25 . These are located north of the buildings around the hangar. 150 $\mathrm{m}$. runways are located in flat areas with no more inclination surface of the track itself.

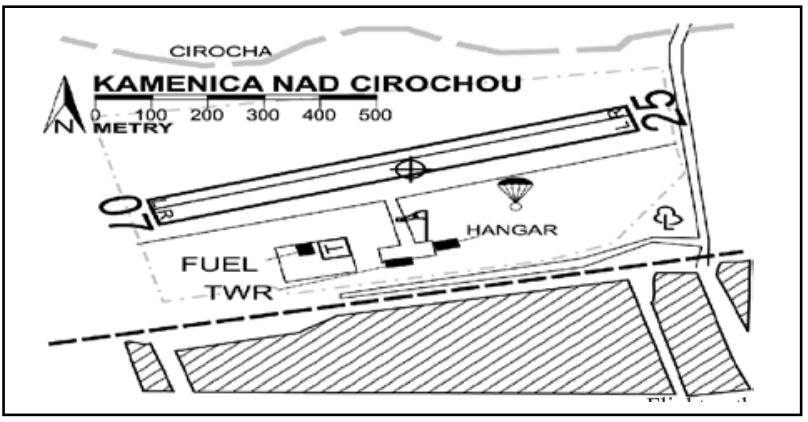

Fig. 4. Location of airport

\section{MEASUREMENT RESULTS}

In different parts of the table zou can see the values for the correction, if it was necessary to modify the resulting data on the speed and tilt correction aircraft Tab.1.

\begin{tabular}{|c|c|c|c|c|c|c|c|}
\hline $\begin{array}{c}\text { Measuring } \\
\text { point }\end{array}$ & $\begin{array}{c}\text { Measurement } \\
\text { time } \\
{[\mathbf{h}]}\end{array}$ & $\begin{array}{c}\mathbf{L}_{\text {ASmax }}, \\
\text { 2h } \\
{[\mathbf{d B}]}\end{array}$ & $\begin{array}{c}\mathbf{L}_{\text {Aeq, 2h }} \\
{[\mathbf{d B}]}\end{array}$ & $\begin{array}{c}\mathbf{\Delta V} \\
{[\mathbf{d B}]}\end{array}$ & $\begin{array}{c}\Delta \mathbf{I}(\mathbf{\varepsilon}) \\
{[\mathbf{d B}]}\end{array}$ & $\begin{array}{c}\mathbf{L}_{\text {korr }} \\
{[\mathbf{d B}]}\end{array}$ & $\begin{array}{l}\mathbf{L}_{\text {Aeq, 2h, }} \\
\text { korr } \\
{[\mathbf{d B}]}\end{array}$ \\
\hline $\mathbf{1}$ & $9: 00-11: 00$ & 97,6 & 67,4 & - & - & - & 67,4 \\
\hline $\mathbf{2}$ & $9: 00-11: 00$ & 88,2 & 59,3 & - & - & - & 59,3 \\
\hline $\mathbf{3}$ & $9: 00-11: 00$ & 91,5 & 65,6 & - & - & - & 65,6 \\
\hline $\mathbf{4}$ & $9: 00-11: 00$ & 88,3 & 59,3 & - & - & - & 59,3 \\
\hline
\end{tabular}

Tab. 1. Summary results plus of the corrections

The noise descriptors measured in the individual measuring points, which were placed in the take-off runway is stated the following conclusions:

- measurement of aircraft noise around the Aeroclub of Kamenica nad Cirochou at the measuring points 1 to 4 is shown that there are not exceeded immission values for determining values of environmental noise at all measuring points in a set time interval,

- it is not necessary to determine the correction for the acceleration of aircraft on take-off runway, because it did not reach maximum speed defined for this type of aircraft,

- the need to establish correct tilt of the aircraft because the aircraft has located the propulsion unit in front and not on the wings,

- noise, which was due to the surrounding environment, is the noise from the remote village of Kamenica Cirochou. Noise from the building reconstruction and traffic is negligible and has no impact on the measured values of air traffic at the airport Aeroclub Kamenica nad Cirochou,

- there is no need to introduce any measures to reduce noise emitted from traffic at the airport Aeroclub Kamenica nad Cirochou.

We can assume that if the future does not change the flight schedule, it stops at the Airport aircraft at a higher power has taken place or reconstruction of the runway take-off from turf to asphalt, we can assume that the noise will increase the burden of air transport and the airport itself. We assume that the noise emissions from aircraft, which are emitted into the environment, will increase the airport. The type of aircrafts, which operated at the airport, it is a ZLIN and Cessna engine, which rank among the older types of single aircraft. For these aircraft we assume that the future will improve their motor units, and in conjunction with the team likely will sound and the noise emitted to the environment around the airport over Aeroclub Kamenica nad Cirochou. This paper was created under the project KEGA no. 3/7426/09.

\section{REFERENCES}

Badida, M.; Majerník, M.; Šebo, M.: Strojárska výroba a životné prostredie. Vienala, Košice, 1998. ISBN 80-7099335-9

Badida, M.; Lumnitzer, E.: Experimental measurements with acoustic camera. In: Annals of MTeM for 2009 and proceedings of the 9th international conference Modern Technologies in Manufacturing. - Cluj-Napoca : MTeM, 2009 P. 321-324. - ISBN 97379370704

Herczner, P. a kol.: Aplikácia metodiky pre šírenie hluku v procese posudzovania akustrickej situácie $v$ okolí železničných tratí. In: Mechanical Engineering 2007 : proceedings of abstracts : Bratislava, November 2007, Bratislava : STU, 2007. ISBN 978-80-227-2768-6

Herczner, P.; Románová, M.; Lumnitzer, E.: Analýza metodiky NMBP Route 96 a jej aplikácia pri rekonštrukcii križovatky ciest 1. Triedy. In: 9. Banskoštiavnické dni 2007 - Zvolen TU, 2007. ISBN 978-80-228-1786-8

Lumnitzer, E.; Badida, M.: The usage of dynamic visualisation by industrial noise source analysis. In: Acta Mechanica Slovaca. Roč. 13, č. 1 (2009), s. 20-24. - ISSN 1335-2393 